\title{
UJI FITOKIMIA DAN AKTIVITAS ANTIOKSIDAN EKSTRAK METANOL DAUN ZODIA (Evodia suaveolens)
}

\author{
Khoirul Ngibad, Lilla Puji Lestari \\ Fakultas IImu Kesehatan, Universitas Maarif Hasyim Latif Sidoarjo \\ Email: khoirul ngibad@dosen.umaha.ac.id
}

\begin{abstract}
Zodia (Evodia suaveolens) plant is commonly used by the community to repel mosquitoes. The plant is native to Papua but has been widely cultivated in Java such as: Batu, Depok, Bogor, Bandung and Surabaya. The aim of this study is to determine the antioxidant activity of zodia leaves methanol extract. In addition, to determine the class of secondary metabolites of the methanol extract of zodia leaves. The extraction process was carried out by maceration method using methanol solvent for 3 days then the filtrate was concentrated using a rotary evaporator. The antioxidant potential of zodia leaves methanol extract was tested using the DPPH method (1,1-Diphenyl-2-picrylhydrazyl) with a UV-Vis spectrophotometer while the determination of secondary metabolite compounds from zodia leaves methanol extract was carried out qualitatively using reagents. The results of the phytochemical test showed that the methanol extract of zodia plant leaves contained group of alkaloid, flavonoids, and tannins compounds while the antioxidant activity test of zodia methanol extract using the DPPH method were shown with an $I C_{50}$ value of 55,69 ppm while These results indicated that the zodia leaves methanol extracts have strong category of antioxidant activity.
\end{abstract}

Key Words: In vitro antioxidants; DPPH; methanol extract of Evodia suaveolens; fitochemical test.

\section{PENDAHULUAN}

Radikal bebas merupakan molekul tidak stabil yang dapat menyebabkan kerusakan sel-sel tubuh manusia. ${ }^{1}$ Radikal bebas dapat dengan mudah bereaksi dengan reactive oxygen species (ROS) atau spesies oksigen reaktif dan menjadikannya menjadi radikal aktif. Bentuk oksigen aktif yang lain adalah radikal oksigen aktif bebas (seperti radikal anion superoksida $\mathrm{O}_{2}$, radikal hidroksil $\mathrm{OH}^{-}$) dan radikal oksigen aktif non bebas (seperti hidrogen peroksida $\mathrm{H}_{2} \mathrm{O}_{2}$, oksigen singlet $1 \mathrm{O}_{2}{ }^{2}$ Radikal bebas yang berlebihan dalam tubuh manusia dapat meningkatkan peroksida lipid, yang diyakini berkontribusi pada perkembangan beraneka ragam penyakit degenerative, seperti penyakit kardiovaskular, rheumatoid arthritis, asma, penyakit paru obstruktif kronis, penyakit neurodegeneratif dan autoimun, dan beberapa kanker. ${ }^{3}$

Antioksidan adalah senyawa yang dapat beraksi dalam penundaan, perlambatan, atau penghambatan reaksi oksidasi. ${ }^{4}$ Berbagai senyawa antioksidan mempunyai kemampuan untuk melakukan penghambatan dalam reaksi rantai oksidatif sehingga mampu memperbaiki kerusakan oksidatif terhadap sel tubuh. ${ }^{5}$ Antioksidan dibagi menjadi 2 macam, yaitu antioksidan sintetik dan antioksidan alami. Antioksidan sintetik yang sangat terkenal digunakan adalah butylated hydroxytoluene dan butylated hydroxyanisole tetapi keduanya bisa mengakibatkan penyakit kanker. ${ }^{6}$ Oleh karena itu, penelitian mengenai potensi tanaman herbal sebagai antioksidan sudah mulai banyak dilakukan. 
Potensi tanaman sebagai obat herbal sudah banyak diteliti ${ }^{7,8}$, salah satunya adalah potensi antioksidan dari beberapa tanaman herbal. Ekstrak etanol buah mengkudu (Morinda citrifolia L.) mempunyai aktivitas antioksidan dalam level sedang yang dibuktikan dengan nilai $\mathrm{IC}_{50}$ sebesar $104,73+4,56 \mu \mathrm{g} / \mathrm{mL}^{9}{ }^{9} \mathrm{Di}$ sisi lain, penelitian tentang Ekstrak etanol secang (Caesalpinia sappan L.) sebagai antioksidan menggunakan metode Ferric Reducing Antioxidant Power (FRAP) menghasilkan aktivitas antioksidan sebesar $13,99 \mathrm{mmol} \mathrm{Fe}(\mathrm{II}) / 100 \mathrm{~g}^{10}$ Aktivitas antioksidan dari ekstrak kulit batang (Bauhinia semibifida Roxb) juga telah diteliti menggunakan metode DPPH dengan hasil terbaik adalah ekstrak metanol dengan nilai $\mathrm{IC}_{50}$ sebesar $16 \mu \mathrm{g} / \mathrm{mL} .^{11}$

Tanaman herbal lain yang secara empiris telah dimanfaatkan oleh masyarakat adalah tanaman zodia (Evodia suaveolens). Selain sebagai tanaman hias, tanaman zodia juga digunakan untuk mengusir nyamuk. ${ }^{12}$ Ekstrak daun zodia mampu menyebabkan kematian atau mortalitas larva nyamuk Aedes aegypti sebesar $49,44 \%{ }^{13}$ Uji toksisitas ekstrak metanol daun zodia meggunakan metodde Brine Shrimp Lethality Test (BSLT) menghasilkan nilai $L_{50}$ sebesar 131,34 ppm. ${ }^{14}$ Penelitian lain menunjukkan bahwa aktivitas minyak atsiri daun zodia mampu menghambat pertumbuhan bakteri Gram positif dan bakteri Gram negatif. ${ }^{15}$

Kandungan kimia daun zodia meliputi: golongan senyawa flavonoid, tannin, alkaloid steroid/ triterpenoid, dan saponin. ${ }^{12}$ Secara umum, senyawa yang berpotensi sebagai antioksidan berasal dari golongan senyawa flavonoid atau polifenol. ${ }^{16}$ Mekanisme kerja golongan senyawa flavonoid/polifenol sebagai antioksidan adalah melalui pemberian 1 elektron kepada elektron tidak berpasangan (ETB) senyawa radikal bebas sehingga mampu menyebabkan penghambatan terhadap reaksi autooksidasi dan penurunan kuantitas radikal bebas. ${ }^{17}$

Penelitian tentang aktivitas antioksidan dari ekstrak metanol daun tanaman zodia belum dilakukan. Oleh karena itu, penelitian ini bertujuan untuk mengetahui aktivitas antioksidan ekstrak metanol daun zodia menggunakan metode DPPH dengan penentuan nilai $\mathrm{IC}_{50}$.

\section{METODE PENELITIAN}

\section{Alat dan Bahan}

Alat yang digunakan dalam penelitian ini adalah spektrofotometer UV-Vis (SHIMADZHU®), rotary evaporator vacuum (Eyela ${ }^{\circledR}$ ), blender, dan ayakan 60 mesh. Bahan-bahan yang digunakan dalam penelitian ini meliputi : serbuk simplisia daun zodia (Evodia suaveolens), pelarut metanol, reagen Dragendroff dan Mayer, logam Magnesium, $\mathrm{HCl} 37 \%, \mathrm{HCL} 2 \%, \mathrm{HCl} 0,05 \mathrm{M}$, $\mathrm{HCl} 1 \mathrm{~N}$, kloroform, aseton, asam asetat anhidrat, akuades, larutan $\mathrm{FeCl}_{3} 1 \%, \mathrm{H}_{2} \mathrm{SO}_{4}$, DPPH (2,2-diphenyl-2-picrylhydrazyl), dan vitamin C.

\section{Pengambilan Sampel}

Daun tanaman zodia segar ditimbang, dicuci dengan air bersih, dipotong kecil-kecil. Selanjutnya, sampel dikeringkan dengan cara diangin-anginkan. Kemudian, sampel diblender dan diayak sampai terbentuk serbuk dengan ukuran 60 mesh.

\section{Pembutan Simplisia}

Pembuatan Ekstrak Metanol Daun Zodia

Sebanyak $100 \mathrm{~g}$ sebuk dimaserasi menggunakan pelarut $250 \mathrm{~mL}$ metanol pada suhu ruang. Proses maserasi dilakukan 
selama 24 jam kemudian disaring menjadi filtrat dan ampas. Filtrat dimasukkan ke dalam wadah dan ampas dikeringkan pada suhu ruang untuk menghilangkan pelarut metanol. Selanjutnya, ampas direndam kembali dengan $150 \mathrm{~mL}$ pelarut metanol baru selama 24 jam kemudian disaring dan ampasnya direndam kembali dengan $100 \mathrm{~mL}$ pelarut metanol baru. Selanjutnya, disaring menjadi filtrat dan ampas. Masing-masing filtrat digabung untuk dipekatkan dengan rotary evaporator sampai diperoleh ekstrak pekat dan dihitung rendemen ekstrak kasar. Selanjutnya ekstrak metanol pekat dari daun tanaman zodia dilakukan uji antioksidan menggunakan metode DPPH. Rendemen ekstrak dihitung menggunakan rumus :

$\%$ Rendemen $=\frac{\text { berat ekstrak }(\mathrm{g})}{\text { berat sampel }(\mathrm{g})} \times 100 \%$

Uji Fitokimia dengan Reagen ${ }^{18}$

Uji fitokimia menggunakan reagen dilakukan untuk uji alkaloid, flavonoid, tanin, saponin dan steroid/terpenoid.

\section{Persiapan Larutan Sampel Uji dan Standar Antioksidan}

Larutan uji /standar antioksidan dibuat dengan konsentrasi $(20,40,60,80$ dan 100) $\mathrm{mg} / \mathrm{L}$ dengan cara ditimbang $(20,40,60,80$ dan 100) mg ekstrak metanol daun zodia dan vitamin $\mathrm{C}$ kemudian masing-masing dilarutkan dalam $1 \mathrm{~L}$ metanol. ${ }^{19}$

\section{Uji Antioksidan menggunakan Metode DPPH}

Campuran reaksi terdiri dari $1 \mathrm{~mL}$ larutan DPPH $6 \times 10^{-5} \mathrm{M}$ dan $33 \mu \mathrm{L}$ larutan metanol yang berisi larutan uji. Setelah inkubasi selama 20 menit pada suhu $37^{\circ} \mathrm{C}$, absorbansi campuran reaksi diukur pada panjang gelombang $515 \mathrm{~nm}$ menggunakan spektrofotometer untuk mendapatkan nilai
Absorbansi. Sampel blanko dengan $33 \mu \mathrm{L}$ metanol dalam larutan DPPH disiapkan dan diukur pada panjang gelombang yang sama. Percobaan dilakukan dengan 3 kali pengulangan. Aktivitas antioksidan dihitung menggunakan rumus sebagai berikut:

Aktivitas antioksidan (\%) = $\frac{\text { Absorbansi kontrol-Absorbasi sampel }}{\text { Absorbansi kontrol }} 100 \%$ Kemudian dibuat grafik hubungan antara konsentrasi sampel (sumbu $\mathrm{x}$ ) dan persen penghambatan (sumbu y). Nilai $I_{50}$ dihitung berdasarkan rumus persamaan regresi.

\section{HASIL DAN PEMBAHASAN}

\section{Uji Fitokimia}

Uji fitokimia merupakan salah satu tahapan penting dalam rangka untuk mengetahui potensi sumber daya tanaman yang berpotensi dijadikan obat baik itu obat herbal terstandar maupun obat fitofarmaka. Uji fitokimia dapat memberikan informasi secara kaulitatif mengenai jenis golongan senyawa metabolit sekunder, seperti flavonoid, alkaloid, saponin steroid, dan terpenoid. Hasil uji fitokimia secara kualitatif menggunakan reagan dari ekstrak metanol daun zodia ditunjukkan dalam Tabel 1.

Berdasarkan Tabel 1, dapat diketahui bahwa ekstrak pekat metanol daun zodia mengandung golongan senyawa alkaloid, flavonoid, dan tannin. Pelarut metanol merupakan pelarut polar yang dapat mengekstrak senyawa polar, senyawa semipolar dan senyawa non polar yang yang mengikat glikosida yang terkandung dalam suatu tanaman yang berpotensi sebagai obat. Hasil penelitian ini juga sesuai dengan hasil penelitian yang dilakukan tentang uji toksisitas dan uji fitokimia dari ekstrak metanol daun zodia yang diperoleh dari Papua. ${ }^{20}$ 
Tabel 1. Hasil uji fitokimia secara kualitatif menggunakan reagen kimia

\begin{tabular}{ccc}
\hline No & Uji & Hasil \\
\hline 1 & Golongan senyawa alkaloid & + \\
2 & Golongan senyawa flavonoid & + \\
3 & Golongan senyawa tannin & + \\
4 & Golongan senyawa saponin & - \\
5 & Golongan senyawa steroid & - \\
\hline 6 & Golongan senyawa terpenoid & \\
\hline Keterangan : & & \\
$+\quad=$ Terdapat golongan senyawa fitokimia &
\end{tabular}

\section{Uji Alkaloid}

Prinsip pada uji alkaloid secara

kualitatif menggunakan reagen adalah adanya pengendapan golongan senyawa alkaloid oleh logam-logam berat seperti; logam bismut. Reaksi yang terjadi pada uji alkaloid menggunakan reagen Dragendorff adalah sebagai berikut: ${ }^{18}$

\section{Reaksi reagen Dragendorff}

$$
\begin{aligned}
& \mathrm{Bi}\left(\mathrm{NO}_{3}\right)_{3} \cdot 5 \mathrm{H}_{2} \mathrm{O}+3 \mathrm{KI} \longrightarrow \\
& \mathrm{Bil}_{3} \downarrow+\mathrm{KI} \longrightarrow \mathrm{Bil}_{3}+3 \mathrm{KNO}_{3}+5 \mathrm{H}_{2} \mathrm{O} \\
&
\end{aligned} \begin{aligned}
& {\left[\mathrm{Bil}_{4}\right]^{-}+\mathrm{K}^{+} \downarrow(\text { dengan } \mathrm{KI} \text { berlebih })}
\end{aligned}
$$

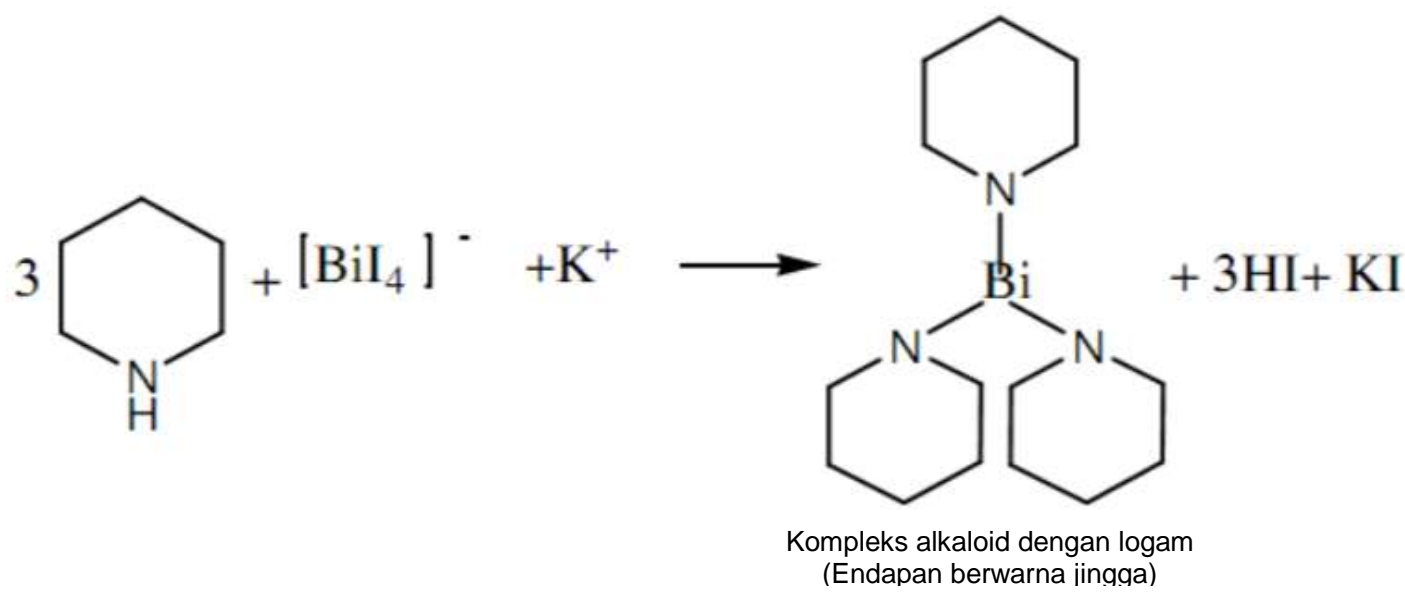

Gambar 1. Reaksi antara alkaloid dan reagen Dragendorff

\section{Uji Flavonoid}

Dalam uji flavonoid, penambahan $\mathrm{HCl}$ pekat berfungsi untuk menghidrolisis flavonoid sehingga terbentuk flavonoid tanp aglikon. Reaksi reduksi dengan $\mathrm{Mg}$ serta $\mathrm{HCl}$ pekat tersebut membentuk senyawa kompleks yang berwarna merah/jingga pada golongan senyawa flavonol, flavanon, dan flavanonol. Reaksi dugaan pada uji fitokimia golongan senyawa flavonoid sebagai berikut. ${ }^{18}$ 


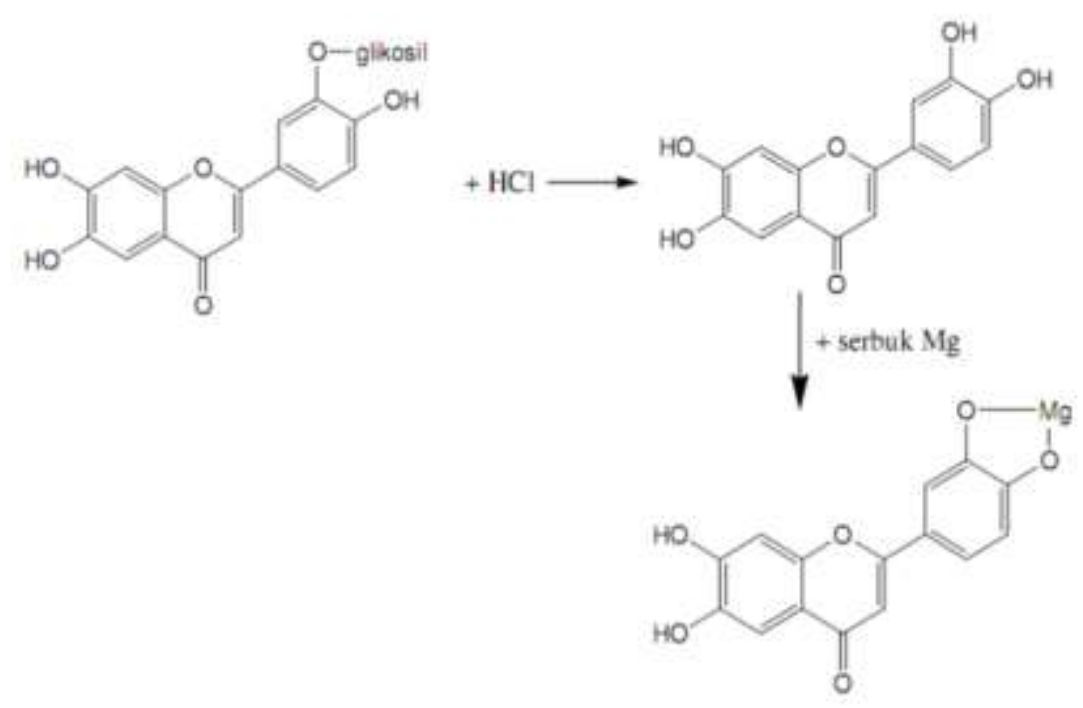

Gambar 2. Reaksi antara flavonoid dan logam Mg

Uji Tanin

Dalam uji tannin menggunakan reagen, timbulnya warna hijau kehitaman pada larutan uji menunjukkan adanya golangan senyawa tanin. Uji fitokimia menggunakan senyawa $\mathrm{FeCl}_{3}$ digunakan dalam penentuan gugus senywa fenol dalam tanaman yang berpotensi sebagai obat herbal. ${ }^{21}$ Dugaan reaksi pada uji tanin dengan $\mathrm{FeCl}_{3}$ sebagai berikut:

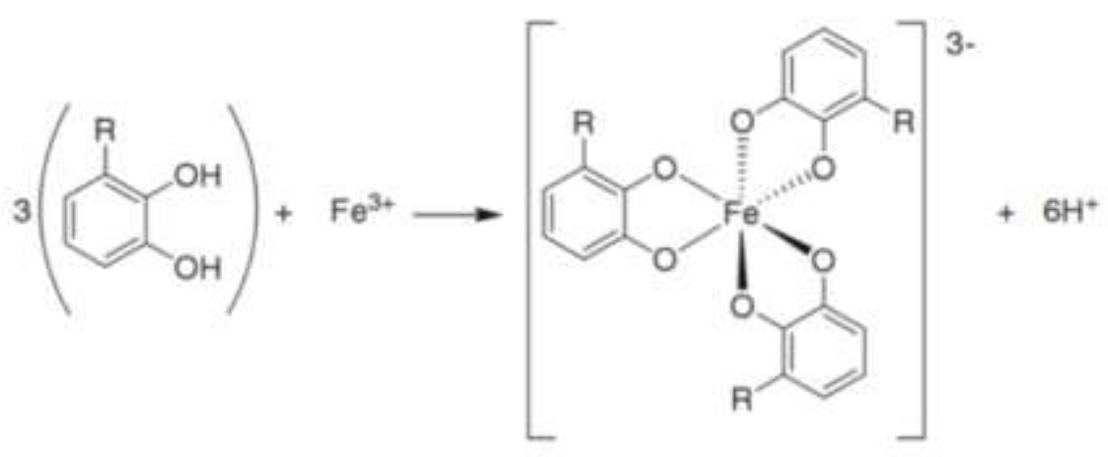

Gambar 3. Koordinasi geometri oktahedral dalam kompleks besi-polifenol ${ }^{22}$

\section{Uji Antioksidan}

Uji aktivitas antioksidan dari ekstrak metanol daun zodia dalam penelitian ini dilakukan menggunakan metode DPPH. Prinsip dari metode DPPH adalah adanya interaksi antara suatu antioksidan dan senyawa kompleks DPPH mampu menetralkan radikal bebas $\mathrm{DPPH} .{ }^{23}$ Adanya aktivitas antioksidan ditunjukkan oleh adanya perubahan warna dalam larutan DPPH dalam metanol yang awalnya berwarna ungu pekat menjadi kuning pucat. ${ }^{24}$ Aktivitas antioksidan dari ekstrak metanol daun zodia dinyatakan dalam persen (\%) penghambatan terhadap radikal DPPH. Persentase penghambatan dapat ditentukan dari adanya perbedaan serapan antara absorben sampel dan absorben blanko yang diukur menggunakan spektrofotometer UV-Vis pada panjang gelombang $515 \mathrm{~nm}$. Hasil uji antioksidan menggunakan metode DPPH dari ekstrak metanol daun zodia ditunjukkan dalam tabel 2 
Tabel 2. Hasil uji antioksidan menggunakan metode DPPH dari ekstrak metanol daun zodia

\begin{tabular}{cccccc}
\hline \multirow{2}{*}{ Konsentrasi (ppm) } & \multicolumn{4}{c}{ Absorbansi (A) } & Persentase penghambatan \\
\cline { 2 - 5 } & $\mathbf{n}_{\mathbf{1}}$ & $\mathbf{n}_{\mathbf{2}}$ & $\mathbf{n}_{\mathbf{3}}$ & Rata-rata & terhadap radikal DPPH (\%) \\
\hline 0 & 1,402 & 1,410 & 1,405 & 1,406 & 0 \\
20 & 1,326 & 1,321 & 1,319 & 1,322 & 8,37 \\
40 & 1,275 & 1,273 & 1,269 & 1,272 & 13,33 \\
60 & 1,214 & 1,219 & 1,199 & 1,211 & 19,50 \\
80 & 1,135 & 1,132 & 1,139 & 1,135 & 27,03 \\
100 & 1,116 & 1,102 & 1,123 & 1,114 & 29,20 \\
\hline
\end{tabular}

Keterangan :

$\mathrm{n}_{1}=$ ulangan $1, \mathrm{n}_{2}=$ ulangan $2, \mathrm{n}_{3}=$ ulangan 3

$\mathrm{IC}_{50}$ adalah konsentrasi larutan dari sampel uji yang diperlukan untuk menghambat $50 \%$ radikal bebas $\mathrm{DPPH}^{25}$ Nilai $\mathrm{IC}_{50}$ dapat ditentukan dengan membuat grafik hubungan antara konsentrasi sampel (sumbu $\mathrm{x}$ ) dan persen penghambatan (sumbu y). Nilai $\mathrm{IC}_{50}$ dihitung berdasarkan rumus persamaan regresi linear. Berdasarkan grafik hubungan antara konsentrasi ekstrak metanol daun zodia dengan $\%$ daya antioksidan perolehan nilai $\mathrm{IC}_{50}$ (Gambar 4), diperoleh persamaan garis regresi linear $y=0,28 x+2,26$. Penentuan nilai $\mathrm{IC}_{50}$ dilakukan dengan cara memasukan angka 50 ke dalam variabel y sehingga nilai $x$ akan diketahui. Nilai $\mathrm{x}$ tersebut merupakan nilai $\mathrm{IC}_{50}$. Dalam penelitian ini, didapatkan nilai $\mathrm{IC}_{50}$ sebesar $170 \mathrm{ppm}$.

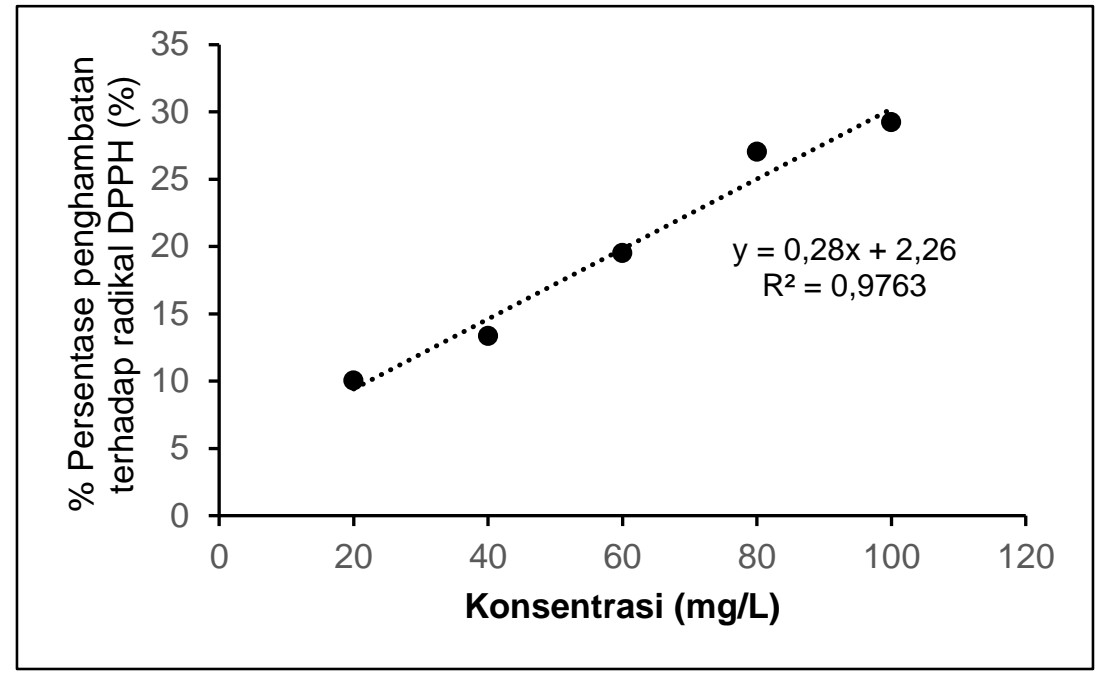

Gambar 4. Grafik hubungan antara konsentrasi ekstrak metanol daun tanaman zodia dengan \% daya antioksidan

Semakin kecil nilai $\mathrm{IC}_{50}$ menunjukkan bahwa aktivitas antioksidan suatu ekstrak semakin besar. Hasil pengujian ekstrak metanol daun tanaman zodia adalah sebesar 170 ppm. Hal tersebut menunjukan bahwa ekstrak metanol daun zodia memiliki aktivitas antioksidan lemah sebab memiliki nilai $\mathrm{IC}_{50}$ antara 150 - 200 ppm. ${ }^{26}$ Hasil uji aktivitas antioksidan tersebut didukung oleh kandungan golongan senyawa metabolit sekunder yang terdapat dalam ekstrak metanol daun zodia.

\section{KESIMPULAN}

Berdasarkan hasil uji fitokimia menggunakan reagen, ekstrak metanol daun tanaman zodia (Evodia suaveolens) mengandung golongan senyawa metabolit sekunder golongan alkaloid, flavonoid, dan tanin. Uji aktivitas antioksidan menggunakan 
metode DPPH dari ekstrak daun tanaman zodia tersebut menghasilkan nilai $\mathrm{IC}_{50}$ sebesar 170 ppm. Dengan demikian, kemampuan ekstrak tersebut sebagai antioksidan tergolong kuat.

\section{UCAPAN TERIMA KASIH}

Penulis mengucapkan terima kasih banyak kepada Direktorat Jenderal Penguatan Riset dan Pengembangan Kementerian Riset, Teknologi dan Pendidikan Tinggi Tahun Anggaran 2019 yang telah mendanai Penelitian Dosen Pemula (PDP) ini dengan No. SK 7/E/KPT/2019 19 Februari 2019 dan Nomor Kontrak Penelitian mono tahun LLDIKTI \& RISBANG : 113/SP2H/LT/DRPM/2019 dan Kontrak Penelitian tahun tunggal antara LLDIKTI dengan UMAHA Tahun 2019 No. 068/SP2H/LT/MONO/L7/2019. Selain itu, penulis juga mengucapkan terima kasih kepada Lembaga Penelitian dan Pengabdian kepada Masyarakat (LPPM) Universitas Maarif Hasyim Latif (UMAHA) Sidoarjo yang telah memfasilitasi selama pelaksanaan penelitian sampai terpenuhinya luaran penelitian.

\section{DAFTAR PUSTAKA}

1. Zhou Yunfenga, Li Lin, Sun Lan, Zhou Lidong $X Y$. In comparison with vitamin C and butylated hydroxytoluene, the antioxidant capacity of aqueous extracts from buds and flowers of Lonicera japonica Thunb. J Tradit Chinese Med. 2019;38(3):373-9.

2. Karuna DS, Dey $P$, Das $S$, Kundu A, Bhakta T. Journal of Traditional and Complementary Medicine In vitro antioxidant activities of root extract of Asparagus racemosus. J Tradit Chinese Med Sci. 2018;8(1):60-5.

3. Samkeliso Takaidza, Fanyana Mtunzi MP. Analysis of the phytochemical contents and antioxidant activities of crude extracts from Tulbaghia species. J Tradit Chinese Med. 2018;38(2):272-9.
4. Ade Ferdinan ABP. Uji Aktivitas Antioksidan dari Ekstrak Jantung Pisang Kepok (Musa paradisiaca L.) Pontianak. J IIm Ibnu Sina. 2018;3(1):88-96.

5. Reksi Sundu, Sapri HN. Uji Fitokimia dan Aktivitas Antioksidan Ekstrak Etanol Umbi Paku Atai Merah (Angiopteris ferox COPEL). J IIm Ibnu Sina. 2018;3(1):97105.

6. Hidayati MD, Ersam T, Shimizu K, Fatmawati S. Antioxidant activity of Syzygium polyanthum extracts. Indones $\mathrm{J}$ Chem. 2017;17(1):49-53.

7. Ngibad K. Efektivitas Kombinasi Ekstrak Etanol Daun Bunga Matahari dan Tanaman Anting-Anting sebagai Antimalaria Secara In Vivo. J Farm Galen. (5(1):12-9.

8. Ngibad K. Kandungan Senyawa Kimia dan Bioaktivitas dari Selaginella doederleinii Hieron. 2018;

9. Anwar K, Triyasmono L. Kandungan total fenolik, total flavonoid, dan aktivitas antioksidan ekstrak etanol buah mengkudu (Morinda citrifolia L.). J Pharmascience. 2019;3(1):83-92.

10. Febriyenti F, Suharti N, Lucida H, Husni E, Sedona O. Karakterisasi dan Studi Aktivitas Antioksidan dari Ekstrak Etanol Secang (Caesalpinia sappan L.). J Sains Farm Klin. 2018;5(1):23-7.

11. Haiyul Fadhli, Ainun Nurain Nurdin MO. Potensi Antioksidan dari Ekstrak Kulit Batang Bauhinia semibifida Roxb. J IIm Ibnu Sina. 2019;4(1):77-87.

12. Isrianto PL. Bisnis Usaha Perbanyakan Tanaman Zodia (Evodia suaveolens) Sebagai Tanaman Pengusir Nyamuk di Kota Surabaya. Inovasi. 2016;18(2):1029.

13. Basundari SA, Tarwotjo U, Kusdiyantini E. Pengaruh Kandungan Ekstrak Daun Zodia (Evodia suaveolens) terhadap Mortalitas Larva Nyamuk Aedes aegypti. Bioma Berk IIm Biol. 2018;20(1):51-8.

14. Lestari MS, Himawan T, Abadi AL, Retnowati R. Toxicity and phytochemistry test of methanol extract of several plants from Papua using Brine Shrimp Lethality Test (BSLT). J Chem Pharm Res. 
2015;7(4):866-72.

15. Maryuni AE. Isolasi dan Identifikasi Senyawa Antibakteri Minyak Atsiri Daun Zodia (Evodia sp.). 2008.

16. Brewer MS. Natural antioxidants: sources, compounds, mechanisms of action, and potential applications. Compr Rev food Sci food Saf. 2011;10(4):221-47.

17. Porkony J, Yanishlieva N, Gordon M. Introduction of Antioxidant. Antioxidants in food: Practical applications. 2001. 1-3 p.

18. Ngibad K. Phytochemical Screening of Sunflower Leaf (Helianthus annuus) and Anting-Anting (Acalypha indica Linn) Plant Ethanol Extract. Borneo J Pharm. 2019;2(1):24-30.

19. Adebiyi OE, Olayemi FO, Ning-Hua T, Guang-Zhi Z. In vitro antioxidant activity, total phenolic and flavonoid contents of ethanol extract of stem and leaf of Grewia carpinifolia. Beni-Suef Univ J Basic Appl Sci [Internet]. 2017;6(1):10-4. Available from:

http://linkinghub.elsevier.com/retrieve/pii/S 2314853516301007

20. Lestari M., Himawan T, Abadi A., Retnowati R. Toxicity and phytochemistry test of methanol extract of several plants from papua using Brine Shrimp Lethality Test (BSLT). J Chem Pharm Res.
2015;7(4):866-72.

21. Harborne JB. Metode fitokimia: Penuntun cara modern menganalisis tumbuhan. Bandung Penerbit ITB. 1987;78.

22. Perron NR, Brumaghim JL. A review of the antioxidant mechanisms of polyphenol compounds related to iron binding. Cell Biochem Biophys. 2009;53(2):75-100.

23. Fathurrachman DA. Pengaruh konsentrasi pelarut terhadap aktivitas antioksidan ekstrak etanol daun sirsak (Annona muricata Linn) dengan metode peredaman radikal bebas DPPH. 2014;

24. Malangngi L, Sangi M, Paendong J. Penentuan kandungan tanin dan uji aktivitas antioksidan ekstrak biji buah alpukat (Persea americana Mill.). J MIPA. 2012;1(1):5-10.

25. Dungir SG, Katja DG, Kamu VS. Aktivitas antioksidan ekstrak fenolik dari kulit buah manggis (Garcinia mangostana L.). J MIPA. 2012;1(1):11-5.

26. Sami FJ, Soekamto NH, Firdaus F, Latip J. Uji Aktivitas Antioksidan Beberapa Ekstrak Alga Coklat Sargassum polycystum dan Turbinaria Deccurens Asal Pulau Dutungan Sulawesi Selatan Terhadap Radikal DPPH. J Kim Ris. 2019;4(1):1-6. 